\title{
Synthesis, Evaluation and Docking Studies of Cholecalciferol Derivative
}

\author{
SULTANAT $^{1 *}$, AYAZ MAHMOOD DAR ${ }^{1}$, ASIM RIZVI $^{2}$ and IMRANA NASEEM ${ }^{2}$ \\ 1Department of chemistry, Aligarh Muslim University, Aligarh - 202 002, India. \\ ${ }^{2}$ Department of Biochemistry, Aligarh Muslim University, Aligarh - 202 002, India. \\ *Corresponding author E-mail: sultanat@ rediffmail.com
}

http://dx.doi.org/10.13005/ojc/300322

(Received: May 30, 2014; Accepted: July 03, 2014)

\begin{abstract}
Improved synthesis of 33-acetoxy-9, 10-seco-19, 8(8)-spiro-5(10), 6-cholestadiene has been reported after reacting cholecalciferol acetate with dimethylbutadiene by incorporating $\mathrm{BF}_{3} \cdot \mathrm{OEt}_{2}, \mathrm{SnCl}_{4}, \mathrm{ZnBr}_{2}, p$-TsOH in toluene under Diels-Alder condition to get better yields. Agarose gel electrophoresis showed the potential in vitro DNA damaging nature while as the comet assay depicted the genotoxic nature by mobilizing the tail of the comet in lymphocytes. The molecular docking depicted the intercalation of steroid derivative with minor groove of the DNA molecule and in this configuration the phosphodiester bond of DNA stabilizes the acetoxy group. The bioactivity score and PASS software analysis confirmed the potential physicochemical features of the compound to act as active drug.
\end{abstract}

Key words: cholestadiene; cholecalciferol; comet assay; gel electrophoresis; docking.

\section{INTRODUCTION}

Developments of efficient methodologies to access large molecules are of special interest. Steroidal compounds are essential to life in various ways. Synthetic derivatives of steroids have also attracted a good deal of attention for the purpose of developing lead compounds in order to cure different biological disabilities ${ }^{1}$. Especially synthesizing the steroids comprising heterocycles have received much attention of the chemists since many of such compounds have been shown to display important pharmacological properties'.
Synthesis of polycyclic skeletons like steroids, have a central place in the development of regio- and stereo chemically controlled synthetic methodology ${ }^{2}$. Boron trifluoride etherate $\left(\mathrm{BF}_{3} \cdot \mathrm{OEt}_{2}\right)$, tin chloride $\left(\mathrm{SnCl}_{4}\right)$, zinc bromide $\left(\mathrm{ZnBr}_{2}\right), p$-toluene sulphonic acid $(p-\mathrm{TsOH})$ has been studied for those reactions which involve formation of carboncarbon or carbon-heteroatom bonds. Because of various advantages incorporated with these compounds, some studies revealed their uses as potential reagents for numerous reactions involving unexpected formation of dioxaspiro compounds ${ }^{3}$. Some representative examples include cycloaddition, 
isomerisation, ring contraction, ring expansion and unexpected rearrangement reactions ${ }^{4-13}$. The DielsAlder pathway is the most studied reaction, showing numerous uses in synthetic procedures and has been intensively studied ${ }^{14}$. The important tool in Diels-Alder chemistry is the activation of dienophiles by Lewis acid ${ }^{15}$. The barrier lies in searching those conditions which promote cycloaddition but without subsequent aromatization. In continuation of our interest in modified steroids ${ }^{16}$, we herein report the synthesis of desired cholecalciferol derivative in presence of different non-chelating Lewis acids like $\mathrm{BF}_{3} \cdot \mathrm{OEt}_{2}, \mathrm{SnCl}_{4}, \mathrm{ZnBr}_{2}, p$-TsOH under Diels-Alder condition and simultaneously study its binding with DNA by gel electrophoresis and molecular docking, and genotoxicity by comet assay.

\section{RESULTS AND DISCUSSION}

\section{Chemistry}

In synthetic organic chemistry, the DielsAlder reaction is the convenient procedure for forming the 6-membered ring systems with potential control over regio- and stereo chemical properties. This high regio- and stereo selectivity typically have resulted in various uses of this transformation in the building of highly sneaker targets ${ }^{17}$. Diels-Alder procedure has shown mature development, depicting the basic importance in synthetic and theoretical

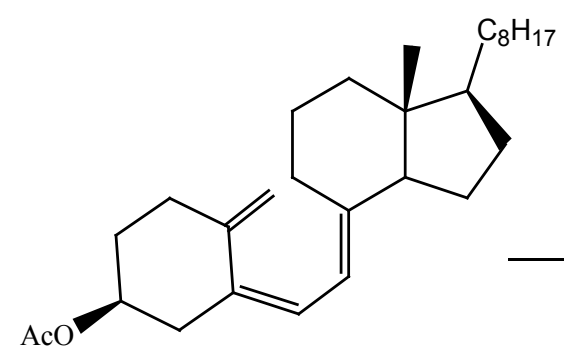

1 sciences. Now a day, this wonderful procedure is one of the most studied and well reviewed, having a beat of incorporations in synthesis. Formulating hetero complexes with different functionalities and their derivatization is the subject of high concern to synthetic scientists. Here we have investigated cyclization behaviour of cholecalciferol acetate with 2, 3-dimethylbutadiene in presence of different reagents like $\mathrm{BF}_{3} \cdot \mathrm{OEt}_{2}, \mathrm{SnCl}_{4}, \mathrm{ZnBr}_{2}, p$-TsOH under Diels-Alder condition in toluene and different yields were obtained. The synthetic strategy adopted to obtain the target product 2 is revealed in scheme 1. The product obtained was characterized by IR, ${ }^{1} \mathrm{H}$ NMR and ${ }^{13} \mathrm{C}$ NMR. The characterization showed close agreement with given structure of compound 2. It is observed that the absence of signal at $\delta 4.2$ in the products of ${ }^{1} \mathrm{H}$ NMR is strongly indicating that the exocyclic methylene is involved in cyclization by intramolecular Diels-Alder reaction. Dimethylbutadiene did not played an important role as the same product was obtained in presence and absence of dimethylbutadiene indicating that reagent is not incorporated. Further intramolecular Diels-Alder reaction is occurring involving terminal methylene for cyclization.

IR spectrum exhibited absorption band at $1026 \mathrm{~cm}^{-1}$ for $\mathrm{C}-0,1735 \mathrm{~cm}^{-1}$ for carbonyl group of acetate and other band at $1655 \mathrm{~cm}^{-1}$ for $(-\mathrm{C}=\mathrm{C}$ -

Scheme 1: Pathway for the synthesis of compound 2

It was found that after subjugating different Lewis and Brønsted acids ${ }^{18}$ like $\mathrm{BF}_{3} \cdot \mathrm{OEt}_{2}, \mathrm{SnCl}_{4}$, $\mathrm{ZnBr}_{2}, p-\mathrm{TsOH}$ and it was found that the maximum

yield was obtained in the order $\mathrm{BF}_{3} \cdot \mathrm{OEt}_{2}>\mathrm{SnCl}_{4}>$ $p-\mathrm{TsOH}>\mathrm{ZnBr}_{2}$.

\begin{tabular}{llccc} 
S. No & Solvent & Lewis and Brønsted acids Acid & Time & Yield \\
\hline 1. & Toluene & $\mathrm{ZnBr}_{2}$ & $3 \mathrm{~h}$ & $55 \%$ \\
2. & Toluene & $p-\mathrm{TsOH}_{3}$ & $2.5 \mathrm{~h}$ & $60 \%$ \\
3. & Toluene & $\mathrm{BF}_{3} \cdot \mathrm{OEt}_{2}$ & $2.25 \mathrm{~h}$ & $83 \%$ \\
4. & Toluene & $\mathrm{SnCl}_{4}$ & $3 \mathrm{~h}$ & $74 \%$ \\
\hline
\end{tabular}


$\mathrm{C}=\mathrm{C}-)$. The ${ }^{1} \mathrm{H}$ NMR spectrum displayed a multiplet centred at $\delta 5.2$ for one proton can be ascribed to $\mathrm{C}_{3}-\alpha \mathrm{H}$, axial. A distorted signal at $\delta$ 5.8- 6.8 can be assigned to the two vinylic protons at $\mathrm{C}_{6}$ and $\mathrm{C}_{7} \cdot{ }^{13} \mathrm{C}$ NMR depicted signals at $\delta 36.3$ for $\mathrm{C}_{3}, \delta 138.2$ for $\mathrm{C}_{5}, \delta 126.2$ for $\mathrm{C}_{6}, \delta 128.2$ for $\mathrm{C}_{9}$. The strategy can also be applied to diverse steroidal derivatives.

\section{Evaluation of In vitro DNA damage using plasmid PBR322}

In vitro DNA damage of compound 2 was assessed using agarose gel electrophoresis as shown in figure 1. Lane 1 shows control plasmid, lane 2 depicts plasmid with incubation of $100 \mu \mathrm{M}$ drug and lane 3 reveals plasmid incubated plus $200 \mu \mathrm{M}$ drug. It is evident from the disappearance of the band and lytic products observed in the gel that the drug is capable of causing DNA damage.
At higher concentration, the disappearance in the band intensity might be the asset of acting the target steroid closely with duplex moiety, which makes the Ethidium bromide to replace.

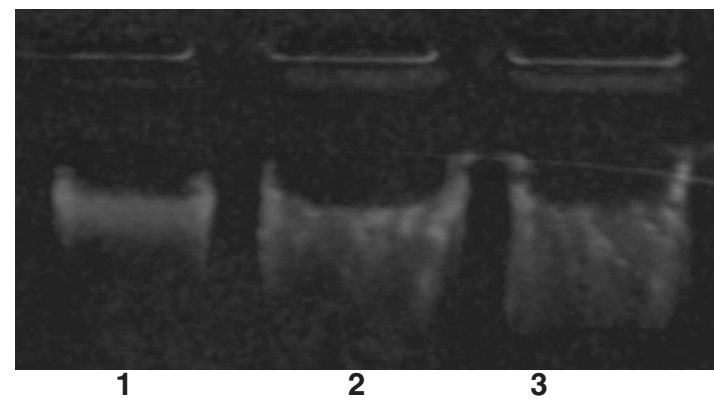

Fig. 1: Agarose gel electrophoretic patterns with lanes 1, 2 and 3 depict DNA only (control), DNA and $100 \mu \mathrm{M}$ comp. 2 and DNA and $200 \mu \mathrm{M}$ comp. 2, respectively

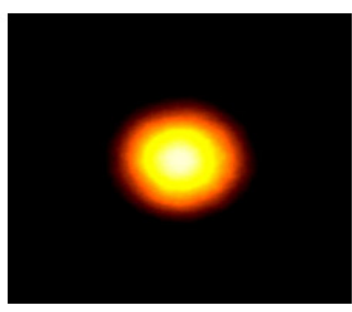

$2 \mathbf{a}$

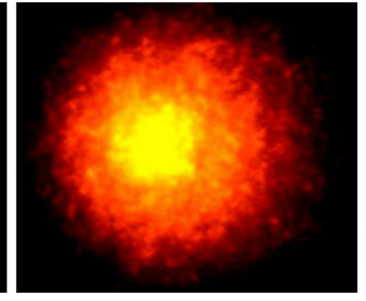

2b

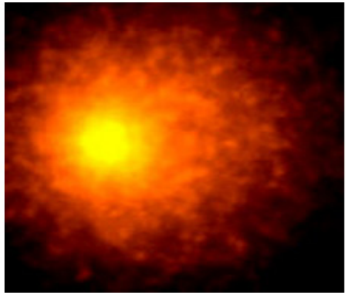

2c

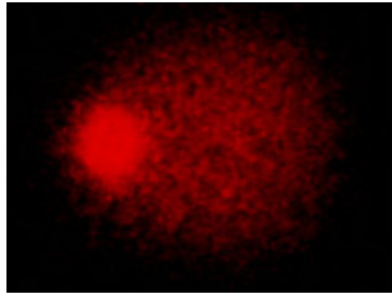

$2 d$

Fig. 2: Depict the interaction of compound and 5-fluorouracil at the various concentrations on the DNA of lymphocytes

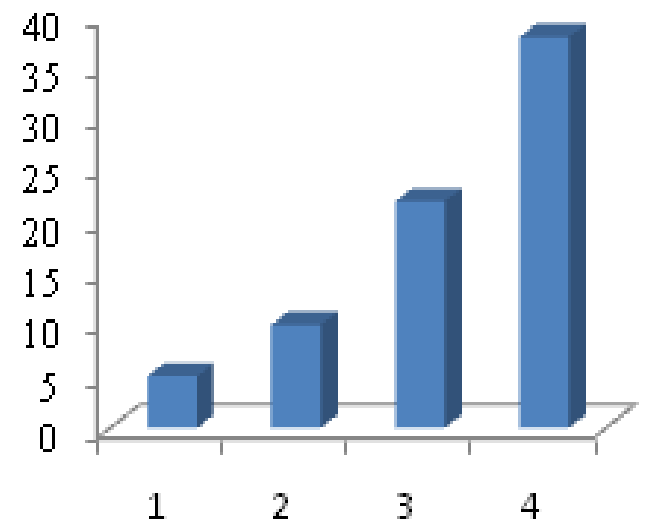

$1=$ Control

$2=(100 \mu g / m L)$ compound

$3=(200 \mu \mathrm{g} / \mathrm{mL})$ compound

$4=5$-Fluorouracil

Fig. 3: Graph confirming the enhancement of apoptotic DNA fragmentation in

lymphocytes with the increase in concentration of compound 2 . The level of damage caused by 5-Fu (100 ìM) was more when compared to the steroid derivative 
Table 1: Tail length Migration in $\mu \mathrm{m}$

\begin{tabular}{ll}
\hline & Tail Length $(\boldsymbol{\mu m})$ \\
\hline Control lymphocyte & $5 \pm 0.25$ \\
Lymphocyte $+100 \mu \mathrm{M}$ compound 2 & $10 \pm 0.36$ \\
Lymphocyte $+200 \mu \mathrm{M}$ compound 2 & $22 \pm 0.54$ \\
Lymphocyte $+200 \mu \mathrm{M}$ 5-fluorouracil & $38 \pm 0.41$ \\
\hline
\end{tabular}

Evaluation of Ex vivo DNA damage using human lymphocytes

Using human lymphocytes, we assessed DNA damage caused by the compound 2 on human genomic DNA ex vivo by comet assay. Figure $2 \mathrm{a}$ shows control lymphocyte in which no comet pattern was observed, figure $2 b$ shows lymphocyte incubated with $100 \mu \mathrm{M}$ drug, figure $2 \mathrm{c}$ shows lymphocyte incubated with $200 \mu \mathrm{M}$ drug and figure $2 \mathrm{~d}$ shows lymphocyte incubated with $200 \mu \mathrm{M}$ 5 -fluorouracil. The compound 2 did not exhibited apoptotic damage to the level of 5-fluorouracil. Tail length migration presented in (Table 1) show that the molecule is capable of causing severe damage to human genomic DNA. The enhancement in DNA damage suggested that steroid derivative induced dose-dependent chromosomal fragmentation leading to apoptosis. The slides were screened for measuring the length of tail shown by the comet after acting with steroid and the outcome is shown in Figure. 3.
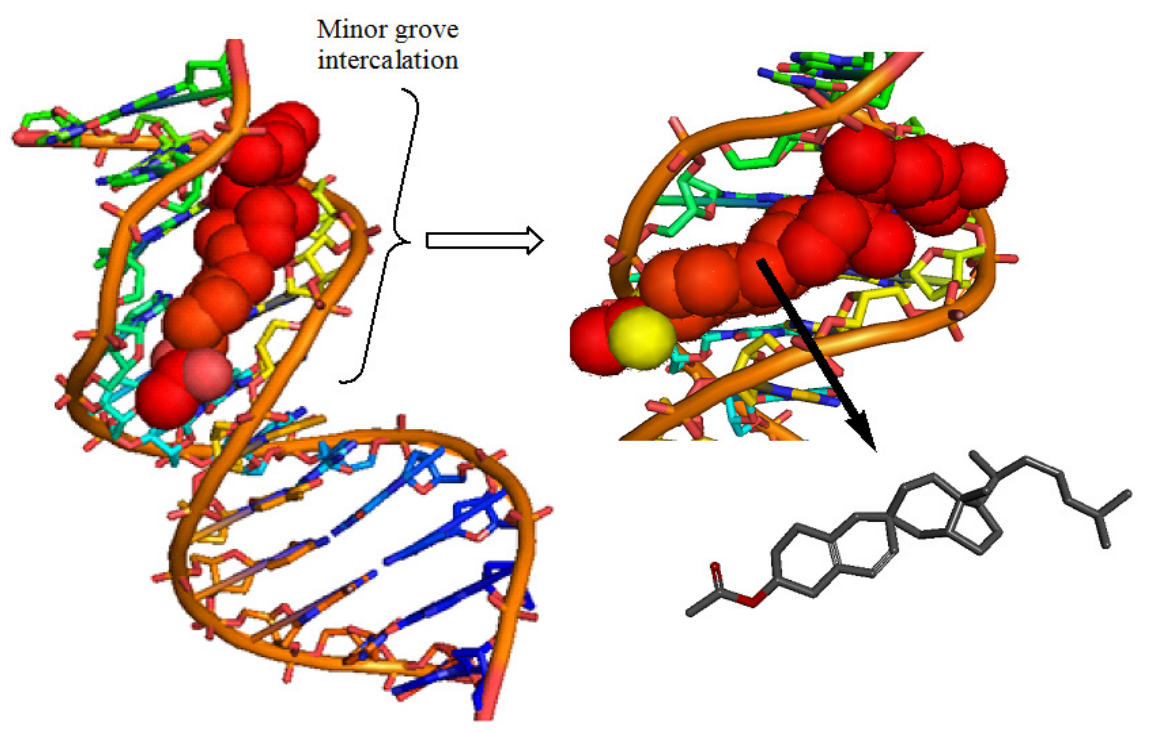

Fig. 4: Model of compound 2-nitrogen bases (downloaded from protein data bank) done by HEX 6.1 software

\section{DNA- compound interaction by molecular docking method}

Here the DNA nitrogen base sequence (taken from Protein Data Bank ID: 1BNA) was docked with compound 2 so as to clarify the target point as well as the expected stable interaction of the steroid in the DNA groove. As evident from figure 4 that compound 2 interacts in the minor groove and in this configuration the $3 \beta$-acetoxy group intercalates with DNA via a phosphodiester bond. The compound did not showed any hydrogen bond but literature reveals that existence of intercalating forces like van der Waals forces or hydrophobic are potentially significant than hydrogen bonding ${ }^{19}$. The resulting decrease in energy of steroid-DNA complex is $-276.5 \mathrm{KJ} \mathrm{mol}^{-1}$ which proves the stable and potent interaction between duplex and steroid molecules. 


\section{Physicochemical properties Bioactivity score}

The bioactivity scores of the compound was also calculated for six parameters, GPCR ligand activity, ion channel modulation, kinase inhibition activity, protease inhibitor, enzyme inhibitor and nuclear receptor ligand activity. As we know for organic molecules, if the bioactivity score is more than 0.00 then, the compound is active, but if it is between -0.50 and 0.00 then the compound is moderately active and if the compound has -0.50 then it is inactive compound. The potential bioactivity score of the compound is given in (Table 2) which clearly show that compound show those properties which are required for the characteristics of compound for acting as a drug.

\section{PASS analysis}

Molecular properties such as membrane permeability and bioavailability are always associated with some basic molecular descriptors such as log $\mathrm{P}$ (partition coefficient), molecular weight (MW), hydrogen bond acceptors and donors count in a molecule. Lipinski used these molecular properties in formulating his "Rule of Five". This rule states that most molecules with good membrane permeability have $\log P \leq 5$, molecular weight $\leq 500$, number of hydrogen bond acceptors $\leq 10$ and number of hydrogen bond donors $\leq 5$. This rule is widely used as a filter for drug-like properties. Although the required molecule did not showed better permeability by showing $\log P>5$ but other parameters like topological surface area, molecular weight, hydrogen bond acceptor and hydrogen bond donor show that compound has potential to act as drug (Table 3). Also by considering the bioactivity score, the overall potential of the compound can be said to be physiologically active.

\section{Fluorescence spectral studies}

At room temperature, compound emit luminescence at $324 \mathrm{~nm}$ respectively in 0.01 tris- $\mathrm{HCl} / 50 \mathrm{mM} \mathrm{NaCl}$ buffer when excited at 260 $\mathrm{nm}$. Fixed amount of compound was titrated with increasing amount of CT DNA, over a range of 5.3 $2.6 \times 10^{-5} \mathrm{M}$ DNA concentration. The addition of DNA caused a gradual decrease in fluorescence emission (Figure 5) intensity being consistent with the nonintercalative binding mode such as electrostatic binding mode (surface binding) and be protected by
Table 2: Depicting the bioactivity score of the compound

\section{Parameters of Bioactivity score}

$\begin{array}{ll}\text { GPCR ligand } & 0.08 \\ \text { Ion channel modulator } & 0.17 \\ \text { Kinase inhibitor } & -0.64 \\ \text { Nuclear receptor ligand } & 0.81 \\ \text { Protease inhibitor } & -0.03 \\ \text { Enzyme inhibitor } & 0.48\end{array}$

Table 3: Showing the physicochemical properties of the compound

Lipinski rule of 5 parameters

$\begin{array}{ll}\text { 1. mi Log } P & 7.767 \\ \text { 2. TPSA } & 26.305 \\ \text { 3. MW } & 426.685 \\ \text { 4. HBA } & 2 \\ \text { 5. HBD } & 0 \\ \text { 6. No-of violations } & 1 \\ \text { 7. N0-of rotatable bonds } & 7\end{array}$

1. The log $P$ value calculated using mol inspiration server 2. Topological polar surface area (defined as a sum of surfaces of polar atoms in a molecule)

3. Molecular weight

4. Hydrogen bond acceptor (expressed as the sum of $O$ and $\mathrm{N}$ atoms)

5. Hydrogen bond donor (expressed as the sum of $\mathrm{OH}$ and $\mathrm{NH}$ )

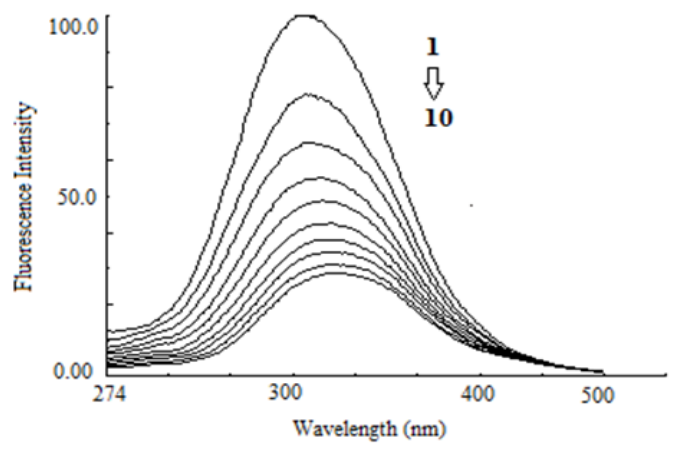

Fig. 5: Emission spectrum of compound in Tris-HCl buffer (pH 7.2) in the presence and absence of CT DNA at room temperature.

Arrow shows change in intensity with increasing concentration of DNA 
DNA efficiently, since the hydrophobic environment inside the DNA helix reduces the accessibility of solvent molecule to the complex, which as a consequence restrict the complex mobility at binding site, leading to a decrease of the vibrational modes of relaxation. Also, the number of bound steroid molecules per DNA ( $n$ ) calculated for was found to be 1.06 from fluorescence spectral data. The binding constant $\mathrm{K}$, determined from the Scatchard equation for compound was calculated to be $1.68 \times 10^{3} \mathrm{M}^{-1}$.

\section{EXPERIMENTAL}

\section{General}

IR spectrum was determined in $\mathrm{KBr}$ with Perkins Elmer 237 spectrophotometer, ${ }^{1} \mathrm{H}$ NMR spectrum were run in $\mathrm{CDCl}_{3}$ on Bruker $\mathrm{AV} 400 .{ }^{13} \mathrm{C}$ NMR was also run in $\mathrm{CDCl}_{3}$ on Bruker DRX 300 and its values are given in ppm. Reaction completion was checked by thin layer chromatography it is cholecalciferol acetate (vit $D_{3}$ ) (commercial substance) was prepared by acetylation of the corresponding sterol with acetic anhydride and pyridine.

Synthesis of 3 3 -acetoxy-9, 10-seco-19, 8(8)-spiro-5(10), 6-cholestadiene (2)

To a solution of cholecalciferol acetate (1 $\mathrm{mol}$ ) in toluene, was added 2, 3-dimethylbutadiene (1 $\mathrm{mol})$ and $\mathrm{BF}_{3} \cdot \mathrm{OEt}_{2} / \mathrm{SnCl}_{4} / \mathrm{ZnBr}_{2} / p-\mathrm{TsOH}(2 \mathrm{~mol}) \mathrm{The}$ refluxing was continued for 2-3 $\mathrm{h}$. After completion, the crude yield was obtained after removing solvent under reduced pressure that was later extracted with ether, recrystallized from ethanol to give an oily compound 2

\section{Characterization}

TLC: $\mathrm{R}_{\mathrm{f}}=0.71$ (Petrol/ether) (3:1); IR $\left(v \mathrm{~cm}^{-}\right.$ 1) $1026 \mathrm{~cm}^{-1}$ (C-O), $1735 \mathrm{~cm}^{-1}\left(\mathrm{OCOCH}_{3}\right), 1655,1629$ $\mathrm{cm}^{-1}$ for diene system. ${ }^{1} \mathrm{H}$ NMR $(500 \mathrm{MHz}) \delta 5.2(\mathrm{~m}$, $\left.1 \mathrm{H}, \mathrm{C}_{3}-\alpha \mathrm{H}\right), \delta 5.8(\mathrm{~d}, 1 \mathrm{H}, \mathrm{CH}), 6.8(\mathrm{~d}, 1 \mathrm{H}, \mathrm{CH}), 2.1$ (s, 3H, OCOCH $H_{3}$ ), 0.69 (s, 3H, $\left.\mathrm{C}_{13}-\mathrm{CH}_{3}\right) .0 .96,0.89$ and 0.81 (other $\mathrm{CH}_{3}$ ); ${ }^{13} \mathrm{C}$ NMR (125 MHz) $\delta(26.5)$ $\mathrm{C}_{1},(27.7) \mathrm{C}_{2},(71.1) \mathrm{C}_{3},(36.3) \mathrm{C}_{4},(135.1) \mathrm{C}_{5},(138.2)$ $\mathrm{C}_{6},(126.2) \mathrm{C}_{7},(35.5) \mathrm{C}_{8},(45.3) \mathrm{C}_{9},(128.2) \mathrm{C}_{10},(21.5)$ $\mathrm{C}_{11},(38.4) \mathrm{C}_{12},(39.5) \mathrm{C}_{13},(55.5) \mathrm{C}_{14},(25.9) \mathrm{C}_{15},(28.8)$ $\mathrm{C}_{16},(56.5) \mathrm{C}_{17},(14.5) \mathrm{C}_{18},(12.7) \mathrm{C}_{19},(29.6) \mathrm{C}_{20},(18.4)$ $\mathrm{C}_{21},(36.4) \mathrm{C}_{22},(24.2) \mathrm{C}_{23},(38.2) \mathrm{C}_{24},(28.2) \mathrm{C}_{25}$, (22.5) $\mathrm{C}_{26}$, (23.5) $\mathrm{C}_{27}$, (170.9), (170.9) $\mathrm{C}_{1}^{\prime}$, (21.5) C2'.

\section{Evaluation of In vitro DNA Damage using plasmid PBR322}

The mixture of buffer $(\mathrm{pH} 7.5,30 \mu \mathrm{l})$, $0.5 \mu \mathrm{g}$ PBR322 DNA and $100 \mu \mathrm{M}$ compound 2 was prepared. The $20 \mu$ solution containing $40 \mathrm{mM}$ ethylenediaminetetraaectic acid, $0.05 \%$ bromophenol blue and $50 \%(\mathrm{v} / \mathrm{v})$ glycerol was added after incubation for $1 \mathrm{~h}$. The mixture was electrophoresized in submarine $1 \%$ agarose paste. UV-transilluminator was used to view and photograph the Ethidium bromide stained gel.

\section{Evaluation of Ex vivo DNA damage by comet assay using human lymphocytes \\ Comet assay confirmed by the method} incarnated and used by Rizvi and co-workers ${ }^{20}$ with certain changes. Normal melting agarose was used to precoat the fully frosted slides and to form a cell suspension, few micro litres of agarose (low m.p) and lymphocytes were mixed and put over the former paste and were put hidden. To solidify agarose, the strains were cooled down for few min in a refrigerator. The removal of cover slips was done gently and another coating of $0.5 \%$ agarose (low m.p) was drawn over the already solidified layer. For solidification, the covered strains were put on the slides and drawn in cold. The removal of covered slips was done and the ice cold lysis buffer was taken in which slides were immersed in for an hour. After lysis in basic electrophoretic medium, the DNA was allowed to unwind. The gel documentation system was worked out at $4{ }^{\circ} \mathrm{C}$ in field strength of $0.7 \mathrm{~V} /$ $\mathrm{cm}$ and $300 \mathrm{~mA}$ current. The strains got neutralized with ice cold $0.4 \mathrm{M}$ buffer $\mathrm{pH} 7.5$, stained with 75 $\mu \mathrm{l} \operatorname{EtBr}(20 \mathrm{mg} / \mathrm{ml})$ and covered with a cover slip. A fluorescent microscope incorporated with CC camera was used to picture the images of strains. Analysis included images of 25 cells in each triplicate. DNA disintegration was measured in terms of the tail length.

\section{Molecular docking}

HEX 6.1 software was used to proclaim the molecular docking studies ${ }^{19}$. HEX is a software program for analyzing the binding energy, depicting stereo chemical interacting modes of ligand with DNA and stability of docked complex. It studies the interaction between the heterocycle and the host (DNA [d(CGCAAATTTCGC) ${ }_{2}$ (PDB ID: 1BNA)] / protein) (as input) in protein data bank format and 
the output is a stable complex deduced with shape complementary and decrease in binding energy criteria. The compound structure was generated by Avagadro 1.01 software using MMFF94 force field. Visualization of the interacted complex has been done by using PyMol (http://pymol.sourceforge.net/) graphic programming ${ }^{21}$. An Intel CORE i5, $2.6 \mathrm{GHz}$ based computer was used to sort the calculations

\section{Determination of physicochemical properties} Bioactivity score and PASS (Prediction of biological activity spectra) analysis

The physicochemical parameters including octanol partition coefficients (miLogP), Mw, HBD, HBA, TPSA and Rotatable bonds were calculated using molinspiration server (http:// www.molinspiration.com/cgi-bin/properties) and ChemAxon (chemicalize.org). The PASS (Prediction of biological activity spectra) approach is based on the structure-activity correlation, Compound activity prediction is done by "comparing" the structure of query compound with the structure of well-known biological active substrate existing in database of the freely available PASS web service. Molecule activity prediction is done by "comparing" the structure of query compound with the structure of well-known biological active substrate existing in database of PASS web service.

\section{Fluorescence Spectral study}

The fluorescence measurements were carried out on a Shimazdu spectrofluorimeter (Model USA), while DNA (5.3 - $\left.2.6 \times 10^{-5}\right)$ pre-treated with compound $\left(4 \times 10^{-5} \mathrm{M}\right)$ for $30 \mathrm{~min}$ in buffer. In the fixed concentration of compound, the emission intensities of DNA were recorded between 274 and $500 \mathrm{~nm}$, at the excitation wavelength of $260 \mathrm{~nm}$.

\section{CONCLUSION}

A convenient and facile route for synthesizing new cholestadiene derivative has been reported. The gel electrophoresis depicted that compound (in comparison to 5-fluorouracil) acts to be active DNA cleaving agent. Comet assay depicted that compound exhibited potential cell apoptosis hence proved to be genotoxic nature. The interactive docking studies undertaken revealed minor groove binding of compound to the DNA molecule. The bioactivity score and PASS analysis also predicted the potential of the compound to act as physiologically active drug. The fluorescence studies also agreed the hypochromism behavior of the compound depicting the decrease in the intensity which also correlates the results with the DNA cleaving ability of the compound as shown in gel electrophoresis.

\section{ACKNOWLEDGEMENTS}

Sultanat, Ayaz M Dar, A. Rizvi and I Naseem are thankful to Chairman of Chemistry Department of AMU, Aligarh for providing research facilities. Dr. Sultanat is thankful to the Department of Science and Technology (DST) New Delhi (India) for providing financial assistance under the women scientist scheme-A.

\section{REFERENCES}

1. Kovacs, D. Kadar, Z. Motyan, G. Schneider, G. Wolfling, J. Zupko, I. Frank, E. Steroids, 2012, 77, 1075-1085.

2. Ballistreri, F. P. Chillemi, R. Sciuto, S. Tomaselli, G. A. Toscano, R. M. Steroids, 2006, 71, 565-577.

3. Xin, Y. Jiang, H. Zhao, J. Zhu, S. Tetrahedron, 2008, 64, 9315-9319.

4. Jiang, H. L. Zhu, S. Z. Synlett, 2006, 9, 13431346.

5. Marshall, J. A. Gill, K. J. Organomet. Chem., 2001,624, 294-299.
6. Van Leeuwen, S. H. Quaedflieg, P. J. L. M., Broxterman, Q. B. Milhajlovic, Y. Liskamp R. M. J. Tetrahedron Lett., 2005, 46, 653-656.

7. Terentev, A. O. Kutkin, A. V. Platonov, M. M. Ogibin, Y. N. Nikishin, G. I. Tetrahedron Lett., 2003,44,7359-7363.

8. Kuhnert, N. Clifford, M. N. Radenac, A.G. Tetrahedron Lett., 2001, 42, 9261- 9263.

9. Stephan, E. Olaru, A. Jaouen, G. Tetrahedron Lett., 1999, 40, 8571-8574.

10. Hardouin, C. Taran, F. Doris, E. J. Org. Chem., 2001,66, 4450- 4452 . 
11. Srikrishna, A. Ramasastry, S. S. V. Tetrahedron Asym., 2005, 16, 2973-2979.

12. Chang, M.Y. Lin, C.H. Chen, Y.L. Chang, C.Y. Hsu, R.T. Org.Lett., 2010,12, 1176-1179.

13. Nakamura, M. Suzuki, A. Nakatani, M. Fuchikami, T. Inoue, M. Katoh, T. Tetrahedron Lett.; 2002, 43, 6929-6932.

14. Gelman, D. M. Forsyth, C. M. Perlmutter, P. Org. Lett., 2009, 11, 4958-4960.

15. Yates, P. Eaton P. J. Am. Chem. Soc., 1960, 82, 4436-4437.

16. Mushfiq, M. Khan, A.R., Shamim, A. Rehman, R. Sultanat, Syn. Comm., 2010, 40, 15081515.
17. Nicolaou, K. C.; Snyder, Scott, A.; Montagnon, Tamsyn, Vassilikogiannakis, Georgios, Ang. Chem. Int. Ed., 2002, 41, 1668-1674.

18. (a) Schinzer, D. In Selectivities in Lewis Acid Promoted Reactions; Kluwer Academic Publishers: Dordrecht, 1989.

(b) Yamamoto, H. Lewis Acids in Organic Synthesis; Ed.; Wiley-VCH: Weinheim, 2000.

19. Mustard, D.; Ritchie, D. W. Struct. Funct. Bioinf., 2005, 60, 269-274.

20. Rizvi, A.; Hasan, S. S.; Naseem, I. PLoS One, 2013, DOI 10.1371/journal.pone.0076191.

21. DeLano, W. L. The PyMOL Molecular Graphics System, DeLano Scientific, San Carlos, CA, USA, (2002). 